\title{
ANALISIS HASIL DRIVE TEST MENGGUNAKAN SOFTWARE G-NET DAN NEMO DI JARINGAN LTE AREA DENPASAR
}

\author{
I Gede Made Yogi Priyandana Adi Saputra ${ }^{1}$, Pande Ketut Sudiarta ${ }^{2}$, Gede \\ Sukadarmika $^{3}$ \\ Program Studi Teknik Elektro, Fakultas Teknik, Universitas Udayana. \\ Email: ypriyandana@gmail.com ${ }^{1}$, sudiarta@unud.ac.id ${ }^{2}$, sukadarmika@unud.ac.id $^{3}$
}

\begin{abstract}
Abstrak
Berkembangnya teknologi telekomunikasi sejalan dengan kebutuhan pelanggan terhadap kecepatan dan kestabilan akses jaringan LTE. Menjamin kualitas jaringan LTE dapat dilakukan dengan pengukuran menggunakan metode drive test pada daerah layanan. Drive test harus dilengkapi dengan software seperti Nemo Handy dan G-Net Track Pro. Nemo Handy merupakan software drive test professional yang banyak digunakan oleh provider, sedangkan G-Net Track Pro merupakan software drive test yang sebelumnya telah diterapkan dalam pembelajaran dikampus. Sehingga hasil pengukuran menggunakan Nemo Handy dan G-Net Track Pro untuk parameter RSRP, RSRQ dan SINR perlu dilakukan perbandingan performance. Dari perbandingan RSRP antara pengukuran dengan teoritis dinyatakan hasil pengukuran Nemo Handy lebih mendekati dibandingkan G-Net Track Pro. Sebagai contoh selisih RSRP pada eNodeB PURADEMAK untuk Nemo Handy diperoleh sebesar $5.96 \mathrm{dBm}$ dan G-Net Track Pro sebesar $9.4 \mathrm{dBm}$. Hal ini disebabkan kelemahan perangkat G-Net Track Pro yaitu tidak memiliki fitur penguncian $\mathrm{PCl}$ seperti pada Nemo Handy sehingga pada beberapa titik pengukuran tidak dapat dibandingkan.
\end{abstract}

Kata Kunci : LTE, Drive Test, Nemo Handy, G-Net Track Pro

\section{Abstract}

The development of technology is connected with customer needs for the speed and stability of LTE network access. Ensuring the quality of the LTE network can be done by measuring using the drive test method in the service area. The test drive must be equipped with software such as Nemo Handy and G-Net Track Pro. Nemo Handy is a professional drive test software that is widely used by providers, while G-Net Track Pro is a drive test software that was previously applied in the learning process at the campus. So that the measurement results using Nemo Handy and G-Net Track Pro for RSRP, RSRQ and SINR parameters need to be compared to performance. From the comparison of RSRP between measurements with theoretical stated Nemo Handy measurement results are closer than G-Net Track Pro. For example, the difference between RSRP in the PURADEMAK eNodeB for Nemo Handy was $5.96 \mathrm{dBm}$ and the G-Net Track Pro was $9.4 \mathrm{dBm}$. This is due to the weakness of the G-Net Track Pro device that does not have the PCl locking feature as in Nemo Handy so that at some point the measurement cannot be compared.

Keywords : LTE, Drive Test, Nemo Handy, G-Net Track Pro

\section{PENDAHULUAN}

Berkembangnya teknologi informasi dan telekomunikasi hingga tersedianya layanan 4G LTE (Long Term Evolution) sejalan dengan kebutuhan pelanggan akan kecepatan dan kestabilan akses suatu jaringan. Bentuk upaya untuk menjamin

kualitas layanan LTE dapat dilakukan dengan pengukuran menggunakan metode drive test. Beberapa penelitian mengenai pengukuran kualitas jaringan dengan metode drive test telah banyak dilakukan sebelumnya diantaranya yaitu Analisa 
Kualitas Sinyal Jaringan GSM pada Menara Rooftop [1], Analisis Kualitas Jaringan UMTS pada Menara Rooftop [2], Analisis Pengaruh Jarak Antara User Equipment dengan EnodeB Teknologi LTE $900 \mathrm{MHz}$ [3].

Pengukuran dengan metode drive test harus dilengkapi software yang mendukung seperti Nemo Handy dan G-Net Track Pro. Kebanyakan pihak provider menggunakan software Nemo Handy dalam melakukan drive test secara profesional. Adapun dengan berkembangnya teknologi telekomunkasi terdapat software G-Net Track Pro yang sebelumnya telah diterapkan dalam pembelajaran dikampus. Namun permasalahan yang akan muncul yaitu apakah hasil pengukuran dengan metode drive test menggunakan G-Net Track Pro sama baiknya jika dibandingkan dengan menggunakan Nemo Handy.

Berdasarkan permasalahan di atas penulis mengangkat, bagaimana hasil pengukuran kualitas layanan sinyal sistem 4G LTE dengan metode drive test menggunakan Nemo Handy dan G-Net Track Pro di area Denpasar pada 3 buah eNodeB yang memiliki ketinggian menara dan frekuensi yang sama. Selanjutnya hasil pengukuran akan dibandingkan dengan hasil perhitungan menggunakan outdoor pathloss model Cost-231Hata dan KPI operator Telkomsel.

\section{KAJIAN PUSTAKA}

Teori-teori penunjang yang digunakan dalam penelitian ini adalah sebagai berikut.

\subsection{LTE (Long Term Evolution)}

LTE atau Long Term Evolution merupakan generasi teknologi seluler keempat yang dikembangkan oleh 3GPP (3rd Generation Partnership Project) yang merupakan teknologi lanjutan dari UMTS (Universal Mobile Telephone Standard). Teknologi LTE mampu melayani kecepatan data puncak downlink mencapai 100 Mbps saat pengguna bergerak cepat dan 1 Gbps saat bergerak pelan atau diam. Serta memiliki kelebihan fleksibel terhadap bandwith yang digunakan mulai dari 1,4 $\mathrm{MHz}, 3 \mathrm{MHz}, 5 \mathrm{MHz}, 10 \mathrm{MHz}, 15 \mathrm{MHz}$, hingga $20 \mathrm{MHz}$ [4].

\subsection{Model Propagasi Cost 231 Hatta}

Cost-231 model adalah pengembangan dari Hatta Model oleh EURO_COST (The European Cooperative for Scientific and Technical Research) untuk PCS (Personality Communication Sistems) pada wilayah urban [4]. Persamaan untuk menghitung model propagasi Cost-231 Hatta pada daerah urban adalah sebagai berikut :

$$
\begin{aligned}
\mathrm{Lp} & =49.3+33.9 \log \mathrm{fc}-13.82 \log \mathrm{hb}-\mathrm{a}(\mathrm{hm}) \\
& +(44.9-6.55 \log \mathrm{hb}) \log \mathrm{d}+\mathrm{CM} \ldots \ldots(1)
\end{aligned}
$$

Faktor koreksi antena mobile untuk area Sub-Urban dan Rural,

$$
\begin{aligned}
\mathrm{a}(\mathrm{hm})= & (1,1 \log \mathrm{fc}-0,7) \mathrm{hm}-(1,56 \log \mathrm{fc} \\
& -0,8) \mathrm{dB} \ldots \ldots \ldots \ldots \ldots \ldots \ldots \ldots \ldots(2)
\end{aligned}
$$

Faktor koreksi antena mobile untuk area Urban,

$\mathrm{a}(\mathrm{hm})=-4,97+3,2(\log 11,75 \mathrm{hm})^{2}$.

Keterangan :

$\mathrm{Lp}=$ Path loss rata-rata $(\mathrm{dB})$

$\mathrm{fc} \quad=$ Frekuensi dari $1500-2000 \mathrm{MHz}$

$\mathrm{hb}=$ Tinggi antena base station mulai dari 4-50 m

$\mathrm{hm}=$ Tinggi antena mobile station mulai dari $1-3 \mathrm{~m}$

$\mathrm{d}=$ Jarak antara MS dan BS mulai dari $0.02-20 \mathrm{~km}[7]$.

\subsection{Mayor Parameter pada Drive Test 4G LTE}

Drive test merupakan suatu kegiatan untuk mengambil data (collecting) sebuah jaringan network dengan menggunakan software dan hardware tertentu. Berikut dibawah ini merupakan mayoritas parameter yang digunakan dalam drive test pada teknologi LTE [4].

\subsubsection{RSRP (Reference Signal Received Power)}

RSRP merupakan sinyal LTE power yang diterima oleh user dalam frekuensi tertentu. Semakin jauh jarak antara site 
dengan user, maka semakin kecil pula RSRP yang diterima oleh user. Parameter RSRP ini digunakan oleh perangkat untuk menentukan titik handover [4].

\subsubsection{RSRQ (Reference Signal Received Quality)}

Merupakan parameter yang menentukan kualitas dari sinyal yang diterima. RSRQ sangat berhubungan dengan RSRP dan RSSI atau dapat didefinisikan sebagai rasio antara jumlah resource block, RSRP terhadap RSSI (Received Signal Strength Indicator) [8]. Nilai standar RSRQ dapat dilihat pada Tabel 1 yaitu :

Tabel 1. KPI Operator Telkomsel Parameter RSRQ [9]

\begin{tabular}{|c|c|}
\hline Nominal & Keterangan \\
\hline $\operatorname{RSRQ}(\mathrm{dB})>=-6$ & Excellent \\
\hline$-9<=$ RSRQ $(\mathrm{dB})<-6$ & Very Good \\
\hline$-12<=$ RSRQ $(\mathrm{dB})<-9$ & Good \\
\hline$-15<=$ RSRQ $(\mathrm{dB})<-12$ & Fair \\
\hline RSRQ $(d B)<-15$ & Bad \\
\hline
\end{tabular}

\subsubsection{SINR (Signal to Interference Noise Ratio)}

SINR merupakan rasio perbandingan antara sinyal utama yang dipancarkan dengan interferensi dan noise yang timbul (tercampur dengan sinyal utama). Parameter ini digunakan oleh operator atau vendor telekomunikasi dalam menentukan hubungan antara kondisi akses radio frekuensi dengan throughput user. [8]. Nilai standar SINR dapat dilihat pada Tabel 2 yaitu :

Tabel 2. KPI Operator Telkomsel Parameter SINR [9]

\begin{tabular}{|c|c|c|}
\hline Nominal & Keterangan \\
\hline & SINR $(\mathrm{dB})>=20$ & Excellent \\
\hline & $10<=\operatorname{SINR}(\mathrm{dB})<20$ & Very Good \\
\hline $0<=\operatorname{SINR}(\mathrm{dB})<10$ & Good \\
\hline & $-5<=\operatorname{SINR}(\mathrm{dBm})<0$ & Fair \\
\hline & $\operatorname{SINR}(\mathrm{dB})<-5$ & Bad \\
\hline
\end{tabular}

\subsection{Drive Test}

Drive test merupakan salah satu bagian pekerjaan dalam optimasi jaringan radio. Drive test bertujuan untuk mengumpulkan informasi jaringan secara real dilapangan. Informasi yang dikumpulkan merupakan kondisi aktual Radio Frekuensi (RF) di suatu eNodeB [4].

\subsubsection{Nemo Handy}

Nemo Handy merupakan software drive test yang sangat cocok dalam melakukan pengukuran baik di luar maupun didalam ruangan. Dalam melakukan drive test Nemo Handy mampu monitoring teknologi jaringan seperti GSM, CDMA, EVDO (Evolution-Data Optimized), WCDMA, HSPA, HSPA+, LTE, dan wireless networks, serta dapat melukukan mobile aplikasi QoS/QoE [5]. Tampilan software Nemo Handy dapat dilihat pada Gambar 1.

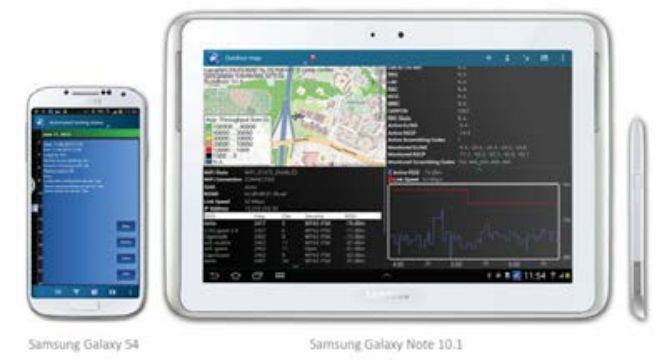

Gambar 1. Tampilan software Nemo Handy pada Handphone Samsung

\subsubsection{G-Net Track Pro}

G-Net Track Pro adalah suatu aplikasi berbasis android untuk melakukan monitoring jaringan UMTS, GSM, LTE, CDMA dan EVDO. Aplikasi ini memonitor service dari CELL ID, LEVEL, QUAL, MCC, MNC, LAC, waktu cell, servis cell yang berdekatan dan levelnya [6]. Tampilan software Nemo Handy dapat dilihat pada Gambar 2.

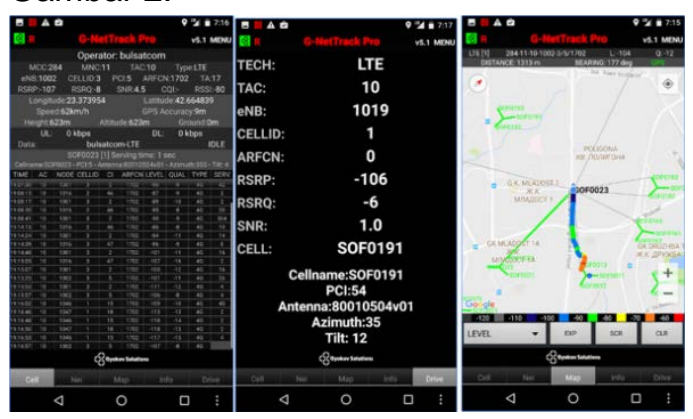

Gambar 2. Tampilan G-Net Track Pro 


\section{METODE PENELITIAN}

Alur analisis pada penelitian yang dilakukan ditampilkan pada Gambar 3.

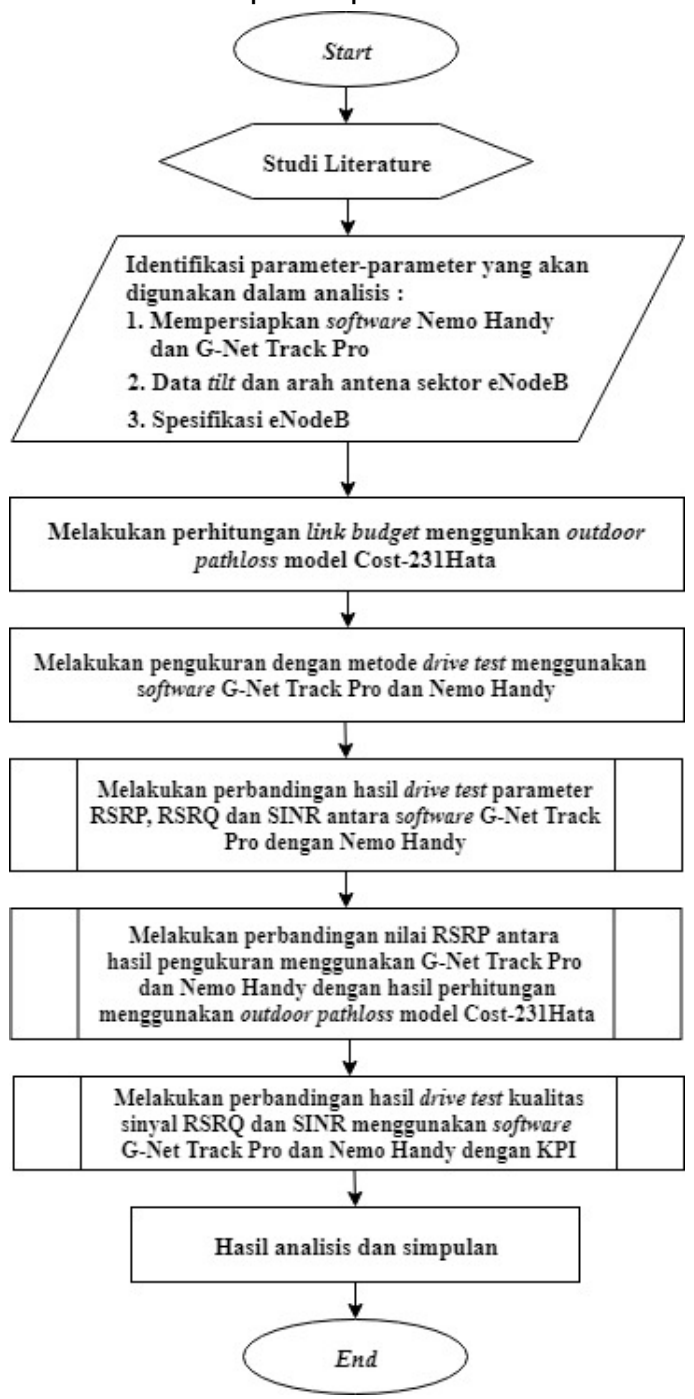

Gambar 3. Alur Penelitian

Secara umum penelitian ini dimulai dengan melakukan studi literatur dengan menggunakan referensi buku, jurnal, dan website di internet yang relevan dan pengumpulan data identitas dari setiap eNodeB pada wilayah penelitian. Selanjutnya melakukan persiapan alat ukur yang digunakan pada penelitian, perangkat yang terinstall software Nemo Handy adalah handphone Samsung Galaxy S5 dan software G-Net Track Pro adalah handphone Xiaomi Redmi 5A. Proses pengambilan data dilakukan secara drive test Single Site Verification (SSV) yang menghasilkan logfiles. Kemudian dilanjutkan dengan menganalisis logfiles sesuai dengan parameter-parameter yang digunakan dalam penelitian.

\section{HASIL DAN PEMBAHASAN}

Secara keseluruhan hasil dan pembahasan pada penelitian ini dapat dijelaskan sebagai berikut.

\subsection{Perbandingan Nilai RSRP Antara Hasil Pengukuran dengan Hasil Perhitungan}

Perbandingan parameter RSRP antara hasil pengukuran menggunakan Nemo Handy dan G-Net Track Pro dengan hasil perhitungan menggunakan model propagasi Cost-231Hata pada eNodeB PURADEMAK dapat dilihat pada Gambar 4.

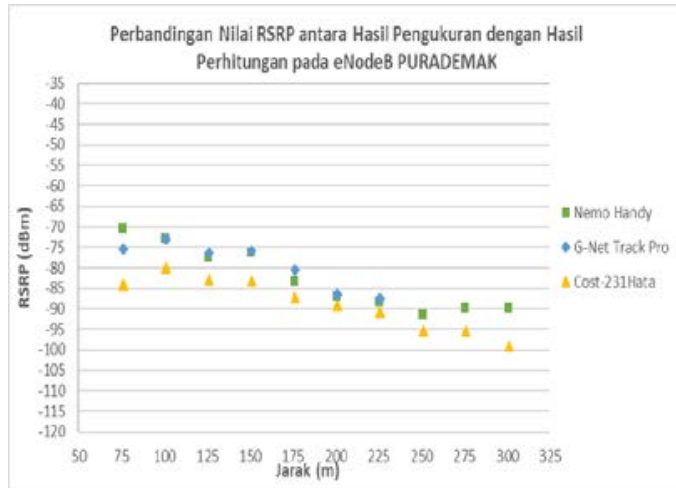

Gambar 4. Perbandingan Nilai RSRP pada eNodeB PURADEMAK

Berdasarkan Gambar 4 terlihat hasil pengukuran G-Net Track Pro dari jarak $250 \mathrm{~m}$ hingga $300 \mathrm{~m}$ tidak dapat ditampikan dan dibandingkan hal ini dikarenakan keterbatasan alat ukur yang digunakan pada G-Net Track Pro yaitu tidak adanya fitur penguncian $\mathrm{PCl}$ seperti halnya Nemo Handy yang menyebabkan perangkat akan mencari nilai RSRP terbesar pada wilayah layanan. Dari Gambar 4 diperoleh selisih rata-rata RSRP hasil pengukuran menggunakan Nemo Handy lebih mendekati dengan hasil perhitungan menggunakan Cost-231Hata 
yaitu sebesar $5.96 \mathrm{dBm}$ dan G-Net Track Pro yaitu sebesar $9.4 \mathrm{dBm}$.

Kemudian perbandingan parameter RSRP pada eNodeB IMAMBONJOL dapat dilihat pada Gambar 5.

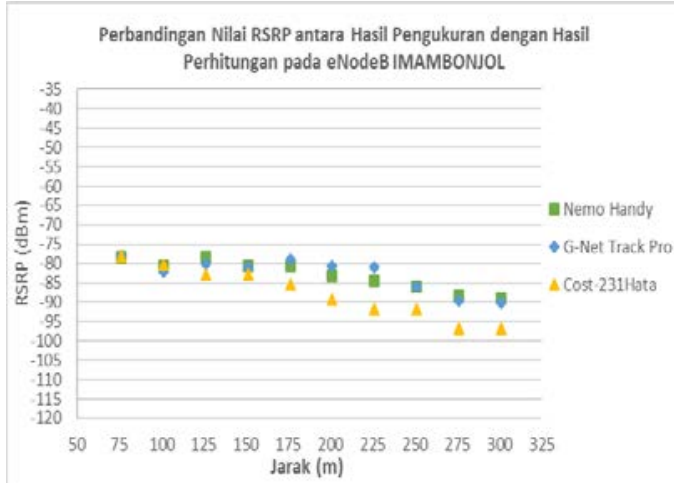

Gambar 5. Perbandingan Nilai RSRP pada eNodeB IMAMBONJOL

Berdasarkan Gambar 5 diperoleh selisih rata-rata RSRP hasil pengukuran menggunakan Nemo Handy lebih mendekati dengan hasil perhitungan menggunakan Cost-231Hata yaitu sebesar $4.62 \mathrm{dBm}$ dan G-Net Track Pro yaitu sebesar $4.87 \mathrm{dBm}$.

Kemudian perbandingan parameter RSRP pada eNodeB AGUNGSAMBIANG dapat dilihat pada Gambar 6.

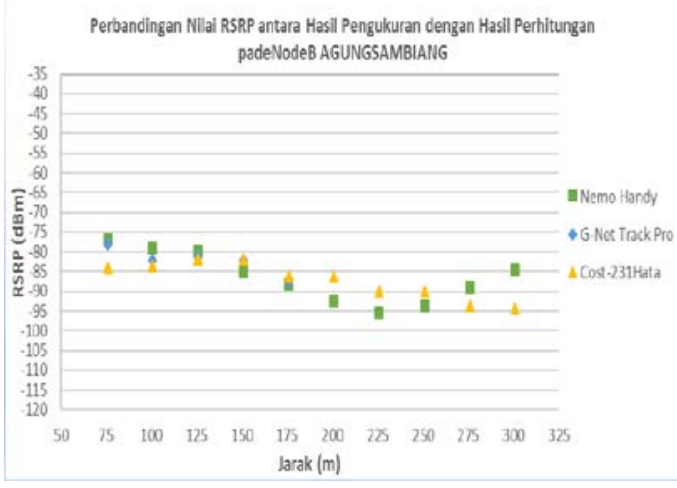

Gambar 6. Perbandingan Nilai RSRP pada eNodeB AGUNGSAMBIANG

Berdasarkan Gambar 6 diperoleh selisih rata-rata RSRP hasil pengukuran menggunakan Nemo Handy lebih mendekati dengan hasil perhitungan menggunakan Cost-231Hata yaitu sebesar $0.75 \mathrm{dBm}$ dan G-Net Track Pro yaitu sebesar $5.05 \mathrm{dBm}$. Hal ini disebabkan hasil pengukuran menggunakan G-Net Track Pro dari jarak $200 \mathrm{~m}$ hingga $300 \mathrm{~m}$ tidak dapat ditampikan dan dibandingkan dikarenakan keterbatasan alat ukur yang digunakan pada G-Net Track Pro yaitu tidak adanya fitur penguncian $\mathrm{PCl}$ seperti halnya Nemo Handy yang menyebabkan perangkat akan mencari nilai RSRP terbesar pada wilayah layanan.

\subsection{Perbandingan Nilai RSRQ Hasil \\ Pengukuran Antara Nemo Handy dan G-Net Track Pro dengan KPI}

Perbandingan parameter RSRQ antara hasil pengukuran menggunakan Nemo Handy dan G-Net Track Pro dengan KPI pada eNodeB PURADEMAK dapat dilihat pada Gambar 7.

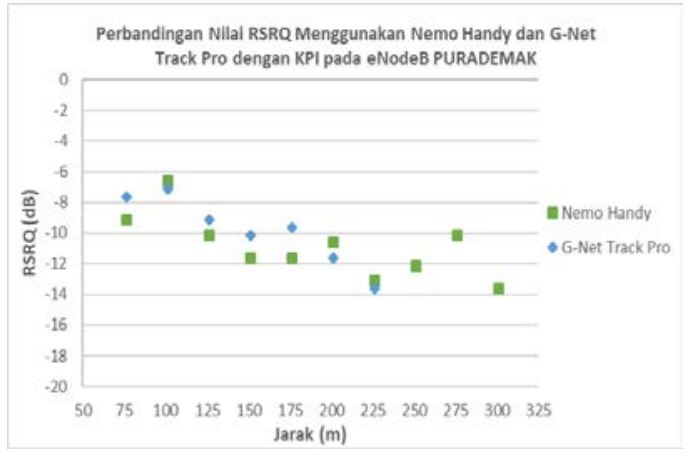

Gambar 7. Perbandingan Nilai RSRQ Pengukuran pada eNodeB PURADEMAK

Berdasarkan Gambar 7 hasil pengukuran kualitas sinyal RSRQ menggunakan Nemo Handy dan G-Net Track Pro pada eNodeB PURADEMAK menujukan kualitas sinyal RSRQ dalam katagori yang baik menurut KPI operator Telkomsel $(-12<=$ RSRQ $(\mathrm{dB})<-9)$. Ini dibuktikan dengan nilai rata-rata RSRQ hasil pengukuran menggunakan Nemo Handy dan G-Net Track Pro yaitu sebesar 10.75 dB dan -9.71 dB.

Kemudian perbandingan parameter RSRQ pada eNodeB IMAMBONJOL dapat dilihat pada Gambar 8.

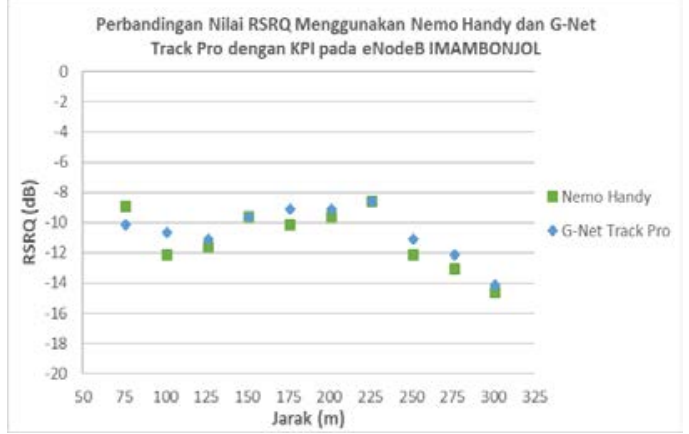




\section{Gambar 8. Perbandingan Nilai RSRQ Pengukuran pada eNodeB IMAMBONJOL}

Berdasarkan Gambar 8 hasil pengukuran kualitas sinyal RSRQ menggunakan Nemo Handy dan G-Net Track Pro pada eNodeB IMAMBONJOL menujukan kualitas sinyal RSRQ dalam katagori yang baik menurut $\mathrm{KPI}$ operator Telkomsel $(-12<=$ RSRQ $(\mathrm{dB})<-9)$. Ini dibuktikan dengan nilai rata-rata RSRQ hasil pengukuran menggunakan Nemo Handy dan G-Net Track Pro yaitu sebesar $10.93 \mathrm{~dB}$ dan $-9.45 \mathrm{~dB}$.

Kemudian perbandingan parameter RSRQ pada eNodeB AGUNGSAMBIANG dapat dilihat pada Gambar 9.

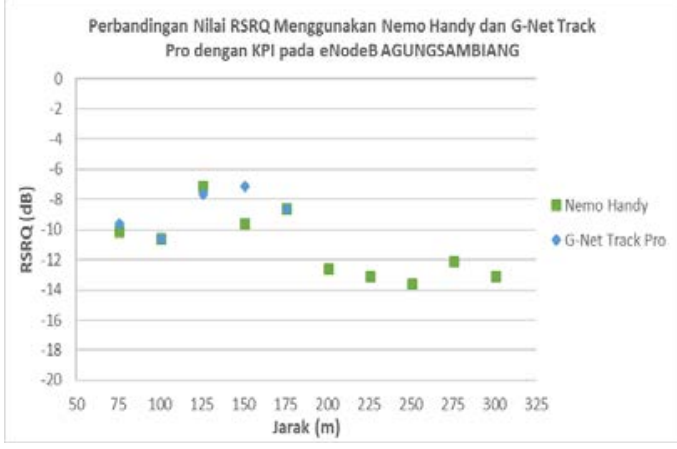

Gambar 9. Perbandingan Nilai RSRQ Pengukuran pada eNodeB AGUNGSAMBIANG

Berdasarkan Gambar 9 hasil pengukuran kualitas sinyal RSRQ menggunakan Nemo Handy dan G-Net Track Pro pada eNodeB AGUNGSAMBIANG menujukan kualitas sinyal RSRQ dalam katagori yang baik menurut KPI operator Telkomsel (-12 <= RSRQ (dB) < -9). Ini dibuktikan dengan nilai rata-rata $R S R Q$ hasil pengukuran menggunakan Nemo Handy dan G-Net Track Pro yaitu sebesar $-10.95 \mathrm{~dB}$ dan -8.6 $\mathrm{dB}$.

\subsection{Perbandingan Nilai SINR Hasil Pengukuran Antara Nemo Handy dan G-Net Track Pro dengan KPI}

Perbandingan parameter SINR antara Hasil pengukuran Nemo Handy dan G-Net Track Pro dengan KPI pada eNodeB PURADEMAK dilihat pada Gambar 10.

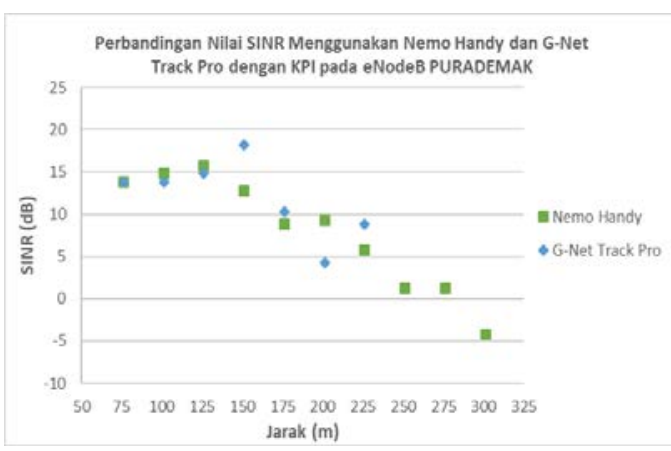

Gambar 10. Perbandingan Nilai SINR Pengukuran pada eNodeB PURADEMAK

Berdasarkan Gambar 10 hasil pengukuran kualitas sinyal SINR menggunakan Nemo Handy dan G-Net Track Pro pada eNodeB PURADEMAK menujukan kualitas sinyal SINR dalam katagori yang baik menurut KPI operator Telkomsel $(0<=$ SINR $(\mathrm{dB})<10)$. Ini dibuktikan dengan nilai rata-rata SINR hasil pengukuran menggunakan Nemo Handy dan G-Net Track Pro yaitu sebesar 8.15 dB dan $12.21 \mathrm{~dB}$.

Kemudian perbandingan parameter SINR pada eNodeB IMAMBONJOL dapat dilihat pada Gambar 11.

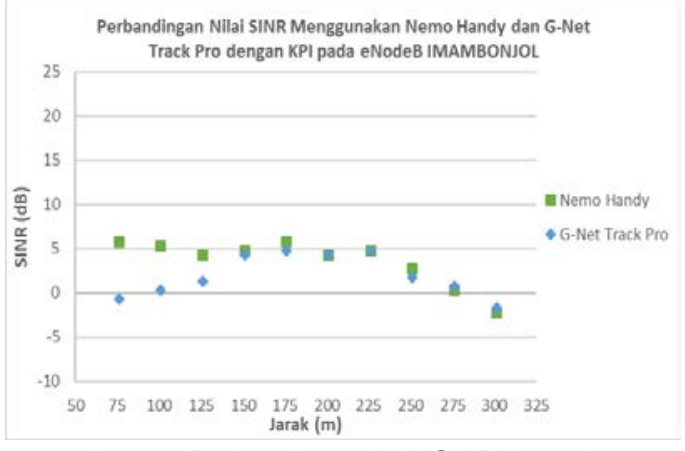

Gambar 11. Perbandingan Nilai SINR Pengukuran pada eNodeB IMAMBONJOL

Berdasarkan Gambar 11 hasil pengukuran kualitas sinyal SINR menggunakan Nemo Handy dan G-Net Track Pro pada eNodeB IMAMBONJOL menujukan kualitas sinyal SINR dalam katagori yang baik menurut KPI operator Telkomsel $(0<=$ SINR $(\mathrm{dB})<10)$. Ini dibuktikan dengan nilai rata-rata SINR hasil pengukuran menggunakan Nemo Handy dan G-Net Track Pro yaitu sebesar $3.8 \mathrm{~dB}$ dan $2.2 \mathrm{~dB}$.

Kemudian perbandingan parameter SINR pada eNodeB AGUNGSAMBIANG dapat dilihat pada Gambar 12. 


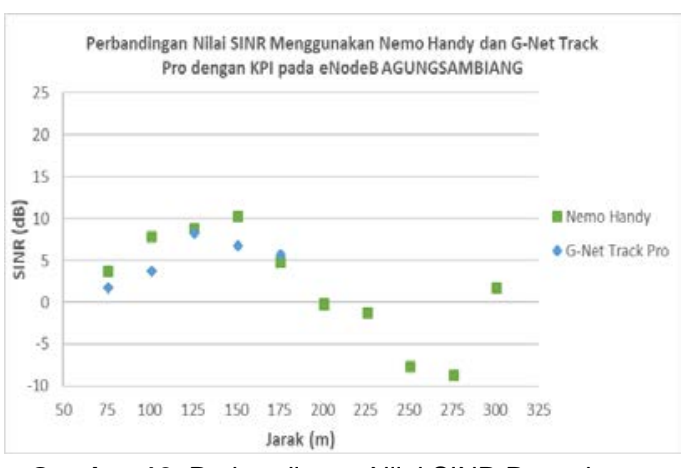

Gambar 12. Perbandingan Nilai SINR Pengukuran pada eNodeB AGUNGSAMBIANG

Berdasarkan Gambar 12 hasil pengukuran kualitas sinyal SINR menggunakan Nemo Handy dan G-Net Track Pro pada eNodeB AGUNGSAMBIANG menujukan kualitas sinyal SINR dalam katagori yang baik menurut KPI Telkomsel (-12 <= RSRQ (dB) $<-9)$. Ini dibuktikan dengan nilai rata-rata SINR hasil pengukuran menggunakan Nemo Handy dan G-Net Track Pro yaitu sebesar $2.15 \mathrm{~dB}$ dan $5.5 \mathrm{~dB}$.

\section{KESIMPULAN}

Berdasarkan hasil analisis dan pembahasan yang telah dilakukan dalam penelitian ini, diperoleh kesimpulan :

1. Kedua alat ukur memiliki kesamaan yaitu masing-masing perangkat dapat menampilkan parameter RSRP, RSRQ dan SINR, namun terdapat beberapa titik pengukuran yang tidak dapat dibandingkan dikarenakan kelemahan perangkat G-NetTrack Pro yaitu tidak memiliki fitur penguncian $\mathrm{PCl}$ seperti pada Nemo Handy yang menyebabkan perangkat akan mencari nilai RSRP terbesar pada wilayah layanan.

2. Hasil pengukuran Level sinyal parameter RSRP menggunakan Nemo Handy secara umum lebih mendekati dengan hasil perhitungan menggunakan Cost-231Hata, Sebagai contoh selisih RSRP pada eNodeB PURADEMAK untuk Nemo Handy diperoleh sebesar $5.96 \mathrm{dBm}$ dan G-Net Track Pro sebesar $9.4 \mathrm{dBm}$.

3. Hasil pengukuran kualitas sinyal Parameter RSRQ dan SINR dari kedua software pada eNodeB PURADEMAK, eNodeB IMAMBONJOL dan eNodeB AGUNGSAMBIANG dibandingkan dengan KPI Telkomsel menunjukan kualitas sinyal RSRQ dan SINR dalam katagori sinyal yang baik.

\section{DAFTAR PUSTAKA}

[1] R. Yanuari, P.K. Sudiarta, N. Gunantara, "Analisa Kualitas Sinyal Jaringan GSM pada Menara Rooftop dengan Membandingkan Aplikasi Metode Drive Test antara Tems Investigation 8.0.3 dengan G-Net Track Pro", E-Journal SPEKTRUM, Vol. 2, No. 4, Desember 2015.

[2] P.P.W. Pramanda, P.K. Sudiarta, N. Indra, "Analisis Jaringan UMTS pada Menara Rooftop dengan Menggunakan Software Tems Investigation dan G-Net Track Pro", EJournal SPEKTRUM, Vol. 3, No. 1, Juni 2016.

[3] I.P.D.K. Pramulia, P.K. Sudiarta, G. Sukadarmika, "Analisis Pengaruh Jarak antara User Equipment dengan eNodeB Terhadap Nilai RSRP (Reference Signal Received Power) Pada Teknologi LTE 900 MHz", EJournal SPEKTRUM, Vol. 2, No. 3, September 2015.

[4] L. Wardhana, B. F. Aginsa, A. Dewantoro, I. Harto, G. Mahardhika dan A. Hikmaturokhman, 4G Handbook Edisi Bahasa Indonesia. Jakarta: www.nulisbuku.com. 2014.

[5] http://literature.cdn.keysight.com/litweb /pdf/5992-2050EN.pdf?id=2827646, diakses tanggal 22 Juni 2017.

[6] http://gyokovsolutions.com/ manuals/gnettrackpro manual.php, diakses tanggal 21 Juni 2017.

[7] M.A. Amanaf, A.R. Danisya, R. Rodian, "Analisis Perbandingan Pemodelan Pathloss COST-231 Hata dan Walfisch Ikegami terhadap Pathloss Pengukuran dengan Metode Drive Test di Wilayah Banyumas", Jurnal Infotel, Vol.9, No.4, November 2017 
[8] A.A. Muayyadi, H. Vidyaningtyas dan N.W.A. Setiawan, "Optimasi Layanan Data pada Jaringan LTE dengan Genex Assistant di Delanggu Klaten", e-Proceeding of Engineering, Vol.4, No.3, Desember 2017.

[9] Key Performance Indicator, Denpasar. PT. Telkomsel Bali Nusra: 2017 